УДК 368.21

Беспалова А.Г., к.е.н., доцент кафедри фрінанси і банківська справа Донецького національного університету ім. Василя Стуса

\title{
КАСКО НА СТРАХОВОМУ РИНКУ УКРАЇНИ: ОЦІНКА ПРИВАБЛИВОСТІ СПОЖИВАЧЕМ
}

Споживачі страхових послуг в Україні за роки існування страхового ринку вже сформували певні пріоритети щодо вибору видів страхового захисту. Треба відзначити, що страхування транспортних засобів $\mathrm{i}$, в першу чергу, з покриттям КАСКО, входить до числа найбільш затребуваних страхових послуг. У статті проведено аналіз розвитку ринку страхування КАСКО, визначено основні чинники впливу на його динаміку, обсяг та споживчу поведінку клієнтів. Проведено аналіз результатів роботи ТОР-10 у сегменті страхування КАСКО, визначено чинники, що впливають на вибір власників автотранспорту виду страхового покриття, страхової компанії та строку договору.

Досліджено цінову політику страхових компаній щодо КАСКО, як інструменту забезпечення балансу інтересів компанії та клієнтів на основі встановлення справедливої оцінки його поведінки у ролі водія.

Ключові слова: страховий ринок, КАСКО, обсяг страхового покриття, страхові тарифи, франшиза, відшкодування збитку.

Табл. 2, Літ. 16

Беспалова А.Г.

\section{КАСКО НА СТРАХОВОМ РЫНКЕ УКРАИНЫ: ОЦЕНКА ПРИВЛЕКАТЕЛЬНОСТИ ПОТРЕБИТЕЛЕМ}

Потребители страховых услуг в Украине за годы существования страхового рынка уже сформировали определенные приоритеты относительно выбора видов страховой защиты. Следует отметить, что страхование транспортных средств и, в первую очередь, с покрытием КАСКО, входит в число наиболее востребованных страховых услуг. В статье проведен анализ развития рынка страхования КАСКО, определены основные факторы влияния на его динамику, объем и потребительское поведение клиентов. Проведен анализ результатов работы ТОР-10 в сегменте страхования КАСКО, определены факторы, которые влияют на выбор владельцев автотранспорта вида страхового покрытия, страховой компании и срока договора.

Исследована ценовая политика страховых компаний относительно КАСКО, как инструмента обеспечения баланса интересов компании и клиентов на основе установления справедливой оценки его поведения в роли водителя.

Ключевые слова: страховой рынок, КАСКО, объем страхового покрытия, страховые тарифы, франшиза, возмещение убытка.

Bespalova A.

\section{CASCO ON THE INSURANCE MARKET OF UKRAINE: EVALUATION OF ATTRACTIVENESS BY THE CONSUMER}

Consumers of insurance services in Ukraine for the years of existence of the insurance market have already formed certain priorities regarding the choice of types of insurance protection. It should be noted that the insurance of vehicles and, first of all, covering the CASCO, is among the most sought after insurance services. The article analyzes the 
development of the insurance market of KASKO, determines the main factors influencing its dynamics, volume and consumer behavior of clients. The analysis of the results of TOP-10 in the insurance segment of CASCO was carried out, factors influencing the choice of vehicle owners for the type of insurance coverage, the insurance company and the term of the contract were determined.

The price policy of insurance companies concerning CASCO is investigated as a tool for ensuring balance of interests of the company and clients on the basis of a fair assessment of its behavior as a driver.

Key words: insurance market, CASCO, volume of insurance coverage, insurance tariffs, deductible, indemnity.

Постановка проблеми. Досвід споживачів страхових послуг та особливо негативний, вчить клієнтів як здобувати якісну послугу, які вимоги потрібно враховувати при виборі страхового продукту та компанії, чітко уявляти призначення такого страхування та його місця в загальній системі управління ризиками щодо володіння та експлуатації транспортного засобу. Характерним для страхового ринку України є низькій рівень охоплення страховими послугами страхового поля: поліс КАСКО в країні мають лише 8\% власників транспортних засобів - для порівняння у країнах Європи цей показник сягає 85\% [11. Така мала частка страхувальників не лише пов'язана із споживчими пріоритетами людей або їх неусвідомленістю щодо ролі страхування у захисті їх майнових інтересів, а, насамперед, визначається станом парку транспортних засобів, $80 \%$ яких старші за 7 років. Такий термін експлуатації транспортних засобів суттєво впливає на їх страхову вартість та доцільність укладання договору страхування. Проте зниження вартості по терміну експлуатації за умовами страхування у більшості страховиків в Україні не завжди є грунтовним, що при таких підходах штучно скорочує потенційний парк для страхування. 3 цього робимо висновок - невелика кількість страхувальників формує недостатній обсяг страхового фонду, що зменшує можливості та обсяги відшкодування збитків. Тому в правилах страхування у розділі «Виключення» більше випадків, за які не сплачується відшкодування, ніж перераховано страхових випадків, які оплачуються. Це також $є$ підставою для негативного відношення до страхування.

Ще важливим чинником використання КАСКО є вартість автомобіля, що визначає фінансову спроможність клієнта. Відомо, що страхування у цивілізованих та економічно розвинутих країнах $\epsilon$ послугою для забезпечених людей, майнове положення яких вимагає використання страхового захисту з максимальним обсягом відповідальності. Такі клієнти в українських компаніях відносяться до VIP, а з огляду на українське суспільство за критерієм платоспроможності, можна винайти дуже малу кількість таких споживачів. Більшість клієнтів обирають договір КАСКО лише при покупці нового автомобілю. Тому розширення страхового поля за рахунок притоку в країну нових транспортних засобів $є$ об'єктивною передумовою потенціалу зростання сегменту КАСКО, але важливим $є$ також поведінка споживачів цих послуг. За дослідженням фахівців поведінка потенційного страхувальника частіше $\epsilon$ ірраціональною [2], тобто «нерозуміння суті страхування взагалі до прийняття спонтанного рішення та укладання договору страхування» [2, С. 156].

3 позицій споживачів оцінка привабливості страхових послуг, в тому числі і КАСКО, базується на співставленні страхового платежу із очікуваннями щодо страхового відшкодування. Найпоширенішим підходом серед клієнтів страхових компаній залишається вибір на користь ціни, тобто розмір страхового платежу $є$ визначальним при страхуванні. На другому місці розміщується відношення до 
страховика, яке формується на основі власного досвіду, або відгуків інших споживачів (найчастіше користуються відгуками в Інтернеті), або звертаються до послуг страхового брокера, частка яких в загальній сумі страхових платежів в Україні щорічно зростає. Між тим більшість власників транспортних засобів в Україні не мають достатніх знань щодо порядку та умов їх страхування, вважають всі види транспортного страхування обов'язковими, а до страхових компаній відносяться 3 упередженням, вважаючи їх недобросовісними учасниками договору. За таких підходів актуальним є питання оцінки привабливості послуг КАСКО на страховому ринку України.

Аналіз останніх досліджень і публікацій. КАСКО $є$ одним 3 найбільш розвинених видів страхування у сегменті послуг для фізичних осіб в Україні - частка премій в загальній сумі становить 19,1\% (ОСЦПВ - 20,4\%) [3]. Цей вид страхування є драйвером для проникнення ідей страхового захисту у суспільство, інструментом формування страхової культури та грамотності, важелем розвитку страхового ринку.

Розвиток теоретичних засад страхування КАСКО у вітчизняному науковому середовищі здійснюється у контексті загальних питань розвитку страхового ринку, з'ясування проблем формування страхової культури, розробки тарифної політики, розвитку діджиталізації у страхових компаніях та інших. Питанням практичного забезпечення страхування автотранспорту присвячені роботи Залєтова О.М., Кнейслер О.В., Стецюк В.М., Толстенко О.Ю. [6], Приказюк Н.В., Моташко Т. П.[5], Ткаченко Н. В., Криниця С. О.[8] та ін. До актуальних питань авто страхування автори віднесли такі: визначення проблем розвитку сектору авто страхування в Україні, вплив страхового захисту на безпеку руху, інноваційний розвиток автотранспортного страхування та окреслення нових векторів в Україні. Стрімкий розвиток ринку транспортних засобів, розробка та впровадження нових технологій щодо їх страхування забезпечують актуалізацію дослідження питань розвитку страхування КАСКО із визначенням поведінки споживачів та їх вподобань. Психологічні аспекти поведінки споживачів на ринку страхування розглядалися Сокіл Л.[2].

Методологічною основою дослідження виступали положення теорії страхування, критичний аналіз наукових поглядів вітчизняних і зарубіжних вчених, досвіду та оцінки ринкової ситуації практиками - менеджментом страховиків та страховими брокерами.

Мета статті - визначити найбільш привабливі 3 позицій споживача умови страхування КАСКО в реаліях українського ринку.

Виклад основного матеріалу. Український страховий ринок $\epsilon$ віддзеркаленням політичних, соціальних та економічних процесів, що відбуваються в країні і він водночас $\epsilon$ місцем впровадження сучасних страхових продуктів світового рівня якості та технологічної забезпеченості, враховуючи той факт, що провідні місця на ринку зайняті страховиками, які представляють всесвітньо відомі страхові групи: AXА, UNIQA, PZU, VIG та інших. Присутність таких продавців на нашому страховому ринку позначається на конкурентних позиціях українських компаній та на споживачах послуг, які мають усвідомити й прийняти нові принципи вибору страхових послуг, відповідні ним цінові рівні, індивідуалізовані підходи до оцінки ризиків й т.п.

За спостереженнями фахівців, які працюють у сегменті авто страхування в Україні, рівень обізнаності страхувальників у питаннях змісту, видів та умов страхування в цілому є недостатньо високим. Всі клієнти можуть бути поділені на такі умовні групи: 
1. Клієнти, що мають досвід страхування та отримували відшкодування збитків. Це більш грамотні страхувальники ніж ті, хто лише мав договір страхування або робить це вперше, бо вони на перше місце при виборі послуги ставлять не ії ціну, а надійність страховика та його політику виплат.

2. Клієнти, які вперше укладають договір КАСКО за необхідністю, наприклад, покупка авто у кредит - практично не обирають страховика та послугу самостійно, вона йде як доповнення до кредитування. Ця група вимушених страхувальників, серед яких все ж таки є обізнані у питаннях страхового захисту люди.

3. Клієнти, що для укладання договору звертаються до послуг страхового брокера. У цій групі вже існують внутрішні підгрупи: а) грамотні клієнти, що чітко формулюють доручення брокеру щодо змісту та умов договору та це, як правило, ті, хто мав проблеми зі страховиком у минулому та бажає перекласти такого роду проблеми на брокера; б) клієнти, які звертаються до брокера з метою прискореного та мінімально витратного способу здобути договір страхування.

В цілому, щоб визначити яке місце на страховому ринку України займає страхування КАСКО та як оцінюють його привабливість споживачі, необхідно дослідити зовнішні чинники впливу на розвиток страхування авто, вимоги до встановлення страхового тарифу, умови договорів страхування та інше. При цьому слід враховувати особливості споживчих пріоритетів страхувальників - фізичних осіб, що пов'язано із довготривалою нестабільною економічною ситуацією в країні. Інноваційні процеси у страхуванні прискорюють трансформацію свідомості споживачів послуг, що все в більшій мірі надаються на віртуальному ринку. Такі зміни технологій страхування у новому тисячоріччі цікаво було б дослідити, порівнявши зміни у страхових інтересах страхувальника на початку історії КАСКО та сьогодення.

Світова історія КАСКО почалася 3 появою перших автомобілів та усвідомленням шкоди та обсягів збитків, що вони спричиняють. Відповідно розвитку автомобілебудування відбувалася й поява продуктів із страхового захисту ризиків експлуатації авто. Розвиток міжнародних відносин, глобалізація економіки, створення безвізових територій та інші чинники призвели до впровадження у національні практики страхування авто найбільш привабливих для учасників страхових відносин умов страхування. В цілому можна визнати, що не лише КАСКО, а більшість сфер страхового захисту мають наднаціональний характер, хоча й базуються на правовій базі конкретної держави. Така особливість пов'язана із відсутністю міжнародних правових норм щодо регламентації страхування КАСКО, оскільки основу у цьому страхування складають лише приватні грошові інтереси власника авто. Проте у солідарній системі страхування $\epsilon$ інтереси загального типу та чинники, що впливають на стан та перспективи розвитку автотранспортного страхування:

- вдосконалення технічних характеристик транспортних засобів викликає суперечливу ситуацію - з одного боку є виробництво високошвидкісних автомобілів (з максимальними значеннями у 255 км на год.), а 3 іншого умови їх експлуатації в переповнених транспортом містах, вимагають обмеження швидкості до 50 км на годину. Поряд 3 цим страховики пропонують своїм клієнтам технічні засоби для точного визначення їх страхового тарифу та інших умов страхування 3 урахуванням особливостей водіння;

- розвиток дорожнього господарства є особливо важливим чинником в Україні, де стан транспортних шляхів вкрай незадовільний та $є$ суттєвим чинником збитків від ДТП, які доволі важко отримати від відомства, що фактично є винуватцем такого стану доріг; 
- поява нових систем безпеки зберігання й експлуатації транспортних засобів;

- зростання добробуту власників транспортних засобів, що впливає на збільшення страхового поля - зростає кількість транспортних засобів і пов'язаних 3 ними інших об'єктів страхування. За 2017 р. в Україні зросла кількість автотранспорту на 139 тис. одиниць. 3 них, нові автомобілі - 82,3 тис.( в тому числі електромобілі - 400 одиниць), вторинна експлуатація - 56,7 тис. од. (електромобілів - 2300 одиниць).

На даний час автомобільна транспортна система України налічує більше 9,2 млн. транспортних засобів, у тому числі: 6,9 млн. легкових автомобілів, 250 тис. автобусів, 1,3 млн. вантажних автомобілів та понад 840 тис. одиниць мототранспорту [16]. Така структура страхового поля свідчить про наявність достатньої кількості зацікавлених у страхуванні осіб, але у відкритому доступі немає інформації про стан цих транспортних засобів у розрізі показників, що впливають на можливості та умови їх страхування, наприклад, невідома структура цих засобів за терміном експлуатації, власності, територіальному розподілу та інших.

- шахрайство з боку страхувальників - власників автотранспорту є проблемою для більшості країн світу. Існують дані про те, що $35 \%$ клієнтів в сфері авто страхування здійснюють шахрайство з метою отримання незаконних виплат [10]. В Україні такі випадки становлять 21\% від всіх випадків страхового шахрайства;

- зростання числа ДТП і тяжкості їхніх наслідків. Кількість ДТП по роках: 2014 p. - 153205, 2015 p. - 138536, 2016 p. - 158176, 2017 p. - 162526. За 6 місяців 2018 р. сталося 68776 ДТП. Частка загиблих людей, із загальної кількості осіб, що потрапили в ДТП: в Англії-2,1\%, Франція - 1,7\%, Україна - 13\%.

- велика кількість викрадень транспортних засобів у країні. За 2014 - 2018 рр. зменшилась кількість угонів: 2014 р. - 1476 од., 2015 р. - 2196, 2016 р. - 2578, 2017 р. 1771 од. Станом на 01.07.2018 р. нерозкритими угонами є 29022 випадки (це загальна кількість угонів, які рахуються у статистиці та ще можуть бути розкриті). До показників, що характеризують даний ризик, відносяться: найбільш піддані угонам марки автомобілів ${ }^{1}$, періоди року 3 найвищими за кількістю угонами та регіональна карта угонів. Щодо періодів угонів, то їх максимальна кількість традиційно припадає на травень - серпень, а за регіонами - лідирують Київ (66,4\%), Одеська область (14\%), Харківська та Дніпропетровська області (разом 19,5\%).

Крім того, у страхуванні КАСКО враховуються вимоги законодавства, традиції страхового підприємництва, суспільні та особистісні потреби споживачів. В переважній більшості розвинених країн, на страхових ринках з високим рівнем конкуренції проводяться дослідження за поведінкою страхувальників - власників авто не лише в цілому, а в розрізі марок машин. Це дає можливість прослідкувати залежність між частотою збитків від ДТП та марки: так у Німеччині встановили, що найбільш обережними є власники авто Fiat та Skoda - частка ДТП від всієї кількості випадків становить 4,6\%, по Mercedes - 5,4\%, та по BMW - 5,2\%. Інтерес мають також дані по страховим компаніям та регіонах, днях тижня та сезонах року. Вся подібна інформація дозволяє страховикам обгрунтовувати розмір страхового тарифу та вносити обмеження до умов страхування з конкретним клієнтом.

Знов виникає протиріччя: страховик бажає залучати власників автомобілів, страхування яких забезпечить йому низький рівень збитковості. Це впливає на зниження страхового тарифу, та водночас веде до зменшення обсягів надходження та зростання витрат на формування баз даних для врахування всіх факторів персонального

\footnotetext{
${ }^{1}$ станом на 1.12.2018 р. лідером в Україні є Toyota - на цю марку припадає 45,5\% всіх угонів
} 
ризику, тобто необхідним $є$ розробка та реалізація нових технологій виявлення, сегментації та оцінки ризиків. В той же час з боку клієнтів може також спостерігатися певне незадоволення щодо надмірного контролю за їх персональними даними, що може мати зворотну дію - зростання шахрайства.

Страховики пропонують в межах тарифної політики відповідні умови страхування - обсяги покриття ризиків та франшизи. Що обирає клієнт 3 множини продуктів КАСКО? Які пропозиції є привабливими для українських страхувальників.

Сегментація інтересів при страхування КАСКО залежить від низки чинників:

I - вік автомобілю:

1.1. Нові автомобілі (строк експлуатації до 2 років) як предмет страхування за договором КАСКО визначають страховий інтерес клієнтів через їх високу вартість. Необхідний для страхувальника ризик - угон, бажано страхувати без франшизи. Навіть незважаючи на додаткові витрати, такий договір страхування $є$ найбільш привабливим для клієнта. Ризики збиток від ДТП та інших причин також є важливими, але вартість їх покриття може за вибором клієнта складати суму меншу ніж вартість автомобіля.

1.2. Автомобілі із строком експлуатації від 3 до 5 років - $\epsilon$ більш привабливими для страхування від ДПТ та збитків від інших подій. На вибір умов страхування для таких авто вже суттєвим чином позначається дійсна вартість автомобіля, розмір франшизи та умови відновлення транспортного засобу після страхового випадку вибір СТО, обмеження по виплатах у договорі та ін. Особливо відчутним для розміру виплати по збитках для Т3 є визначення їх дійсної вартості. Така вартість визначається або на дату укладання договору страхування, або на дату настання страхового випадку. Ïї основу визначає ринкова вартість Т3, що встановлюється для аналогічного виду Т3 на ринку з метою його відчуження та 3 якою згодні покупець та продавець. Розмір дійсної вартості ТЗ на момент укладання договору страхування має вплив на вибір ризиків та, в першу чергу, ризику «Викрадення», який за розміром тарифу значно вищій за інші ризики. Доцільністю страхування цього ризику з урахуванням терміну експлуатації ТЗ з кожним роком зменшується.

1.3. Автомобілі понад 5 років експлуатації втрачають вартість майже наполовину - за методиками оцінки страховиками коефіцієнт залишку вартості авто на шостому році експлуатації становить $32 \%$, тобто лише третина від вартості нового авто може бути відшкодована за страховим випадком. 3 метою підвищення вартості авто такого віку страховики можуть використовувати коефіцієнти різниці пробігів (фактичного та нормативного), встановлювати підвищуючи коефіцієнти в залежності від способів використання авто та інших факторів, що впливають на реальну вартість у бік іï підвищення. Задля залучення до КАСКО клієнтів в цьому сегменті страхового поля автотранспортних засобів пропонуються певні пільги та умови страхування. Але суми відшкодувань можуть незадовільнити страхувальників через неповне покриття збитків, особливо тих що потребують придбання нових деталей для ремонту автомобіля. Враховуючи, що переважну частину транспортних засобів складають авто іноземного виробництва, деталі до яких купуються за валюту та коливання й високий курс валюти, витрати на відновлення будуть значними. Якщо страхувальник уклав договір КАСКО з покриттям по пропорційній системі, то його виплата також буде відповідно зменшена.

II. Умови страхування. Це найбільш складна частина для визначення привабливості з боку страхувальників, тому що порівняння здійснюється за чинниками, які за змістом не мають тотожних параметрів - навіть формулювання ризиків має різне наповнення. Наприклад, ризик «Угон» (частіше називатися «Викрадення») у кожного 
страховика має своє наповнення і щоб переконатися в цьому, порівняємо його зміст по трьох провідних компаніях ${ }^{2}$ : АХА Страхування, УНІКА та Арсенал-Страхування (табл.1) [13-15].

Таблиця 1 - Визначення змісту ризиків за договором КАСКО автотранспорту в правилах страхування

\begin{tabular}{|c|c|c|c|}
\hline Ризик & $\begin{array}{l}\text { АХА Страхування } \\
\text { (2018 рік)* }\end{array}$ & $\begin{array}{c}\text { УНIКА } \\
\text { (2015 рік)* }\end{array}$ & $\begin{array}{c}\text { Арсенал Страхування } \\
\text { (2006 рік)* }\end{array}$ \\
\hline Викрадення & $\begin{array}{l}\text { Незаконне заволодіння Т3 } \\
\text { шляхом крадіжки, грабежу, } \\
\text { розбою, що призвело до } \\
\text { втрати (відсутності) Т3 }\end{array}$ & $\begin{array}{l}\quad \underline{\text { Незаконне }} \\
\stackrel{\text { заволодіння» }}{\text { Будь яке незаконне }} \\
\text { заволодіння Т3 }\end{array}$ & $\begin{array}{c}\text { Незаконне } \\
\text { заволодіння Т3 } \\
\text { шляхом крадіжки, } \\
\text { грабежу, розбою }\end{array}$ \\
\hline $\begin{array}{c}\text { Збиток } \\
\text { внаслідок } \\
\text { ДТП }\end{array}$ & $\begin{array}{c}\text { Будь яке пошкодження або } \\
\text { знищення ТЗ , його окремих } \\
\text { складових частин або } \\
\text { додаткового обладнання } \\
\text { внаслідок ДТП }\end{array}$ & $\begin{array}{c}\text { «ДТП» } \\
\text { Дорожньо- } \\
\text { транспортна пригода, } \\
\text { в тому числі викид } \\
\text { каменів з під коліс } \\
\text { транспорту }\end{array}$ & $\begin{array}{l}\text { «Зббитки в наслідок } \\
\text { ДТП» } \\
\text { Будь яке } \\
\text { пошкодження або } \\
\text { знищення ТЗ, його } \\
\text { окремих частин }\end{array}$ \\
\hline $\begin{array}{c}\text { Збиток } \\
\text { внаслідок } \\
\text { інших } \\
\text { причин }\end{array}$ & $\begin{array}{c}\text { Викрадення частин Т3, повне } \\
\text { пошкодження внаслідок } \\
\text { ПдтО, стихійного лиха, } \\
\text { пошкоджень від інших } \\
\text { причин } \\
\end{array}$ & $\begin{array}{l}\text { «ПДТО» } \\
\text { Протиправні дії } \\
\text { третіх осіб, крім } \\
\text { незаконного } \\
\text { заволодіння Т3 } \\
\end{array}$ & $\begin{array}{c}\text { Збитки від ПДТО, } \\
\text { стихійного лиха, } \\
\text { падіння різних } \\
\text { предметів на ТЗ }\end{array}$ \\
\hline $\begin{array}{l}\text { Інші види } \\
\text { ризиків }\end{array}$ & $\begin{array}{c}\text { «3биток внаслідок поломки» } \\
\text { Повне або часткове } \\
\text { припинення функціонування } \\
\text { ТЗ внаслідок поломки } \\
\text { окремих частин Т3 } \\
\end{array}$ & $\begin{array}{l}\text { «Стихійне лихо», } \\
\text { «Пожежа», } \\
\text { «Інші випадки» }\end{array}$ & $\begin{array}{c}\text { Інші види ризиків не } \\
\text { передбачені } \\
\text { Правилами } \\
\text { страхування }\end{array}$ \\
\hline
\end{tabular}

* - рік затвердження в компанії Правил страхування, діючих на момент написання статті

В компаніях «УНІКА» та «Арсенал Страхування» на відміну від СК «АХА Страхування» не підлягають страхуванню поломки Т3, а також дещо інакше називаються ризики: ризик «Викрадення» має назву «Незаконне заволодіння ТЗ», а також до збитків внаслідок інших причин віднесені протиправні дії третіх осіб та збитки від стихійного лиха, пожежі та інші.

Порівняння змісту ризиків та їх назви дозволяє констатувати їх схожість, але вони мають доповнюватися виключеннями, що містяться в Правилах страхування кожної компанії та можуть суттєво звужувати обсяг страхової відповідальності за кожним ризиком. Їх оцінку важко провести навіть фахівцям із страхування, а страхувальники лише тоді зможуть усвідомити роль таких обмежень, коли на собі випробують їх вплив на розмір відшкодування або отримають відмову у його виплаті. До найбільш розповсюджених виключень відносяться:

1. Загальноприйняті події, що не підлягають страховому захисту: війна, військові дії, громадянські заворушення, ядерна реакція (все це так звані форс-мажорні обставини).

\footnotetext{
2 За 9 місяців 2018 року по валових преміях по страхуванню КАСКО
} 
2. Збитки, що виникли 3 вини та через необережність та необачність страхувальника або його представника.

3. Збитки, які є наслідком використання ТЗ у діяльності, для якої він не передбачений та не заявлений у договорі страхування (наприклад, таксі, участь у спортивних змаганнях (ралі), перевезення небезпечних речовин та предметів, тощо).

Проте в кожній компанії є свої виключення зі страхового покриття в КАСКО, які $\epsilon$ результатом досвіду компанії та іiї політики на ринку.

Таким чином, перед клієнтом постає задача обрати такий набір ризиків, що буде покривати його потребу у страховому захисті та за виключеннями буде привабливішим від пропозицій конкурентів. Зробити такий аналіз неосвіченому у питаннях страхування клієнту не дуже просто, тому, як правило, страхувальник використовує інформацію з Інтернет ресурсів або прислуховується до порад представника компанії чи інших осіб, яким він довіряє. Останнім часом розвитку отримали послуги страхових брокерів, які формують комерційну пропозицію із 3-5 страхових компаній та визначають вигоди клієнтів. Більш детальний аналіз страхового продукту компанії передбачає порівняння за показниками, що мають суттєве значення для КАСКО термін експлуатації Т3, яке приймається на страхування, умови страхування ризику «Викрадення», наявність системи «бонус - малус», розстрочки платежу та інші. На Правилах страхування обраних компаній було складено таблицю 2, до якої обрали найбільш впливові на вибір страхувальника параметри продукту 3 КАСКО. В результаті отримали на доповнення до визначення ризиків такі параметри привабливості страхування:

- за терміном експлуатації ТЗ - економічно недоцільним є страхування «старих» авто, тобто більше 10 років - у Свропі цей термін нижче - 7 років;

- страхування ризику «Викрадення» тільки в сукупності з ризиком збитків від ДТП та інших причин, що забезпечує компаніям додаткові страхові платежі, а їх клієнтам витрати (лише УНІКА пропонує страхування кожного ризику окремо);

- система бонус-малус з наведених компаній є лише в Арсенал Страхування, але вона має сенс при довготривалому страхуванні протягом як мінімум 4 років, коли знижка буде $27 \%$. Позитивним $є$ можливість отримання такої знижки на інші транспортні засоби клієнта;

- всі три страховики надають розстрочку при сплаті страхової премії, але не вказаний порядок іiї надання та умови страхового забезпечення на період розстрочки. 3 правил страхування неможливо встановити чи буде зростання розміру премії при розстрочці, що зазвичай $є$ в такому страхуванні.

Таблиця 2 - Інші умови страхування КАСКО, які впливають на вибір страхувальника щодо укладання договору страхування

\begin{tabular}{|c|c|c|c|}
\hline Умови страхування & $\begin{array}{c}\text { АХА Страхування } \\
\text { (2018 рік)* }\end{array}$ & $\begin{array}{c}\text { УНІКА } \\
\text { (2015 рік)* }\end{array}$ & $\begin{array}{c}\text { Арсенал } \\
\text { Страхування } \\
\text { (2006 рік)* }\end{array}$ \\
\hline $\begin{array}{c}\text { Строк експлуатації } \\
\text { Т3 }\end{array}$ & До 15 років & $\begin{array}{c}\text { мототехніка, легкові } \\
\text { авто - до 10 років, } \\
\text { вантажні авто та } \\
\text { автобуси - до } 15 \\
\text { років }\end{array}$ & До 10 років \\
\hline $\begin{array}{c}\text { Умови страхування } \\
\text { ризику } \\
\text { «Викрадення» }\end{array}$ & $\begin{array}{c}\text { Страхується лише із } \\
\text { ризиком «Збиток }\end{array}$ & $\begin{array}{c}\text { Може страхуватися } \\
\text { окремо від інших }\end{array}$ & $\begin{array}{c}\text { Страхується разом } 3 \\
\text { ризиками «Збиток від }\end{array}$ \\
\hline
\end{tabular}




\begin{tabular}{|c|c|c|c|}
\hline $\begin{array}{c}\text { у договорі } \\
\text { страхування }\end{array}$ & внаслідок ДТП» & ризиків & $\begin{array}{c}\text { ДПТ» та «3битки від } \\
\text { інших причин» }\end{array}$ \\
\hline $\begin{array}{c}\text { Умови визнання } \\
\text { тотального збитку }\end{array}$ & $\begin{array}{c}\text { Більше 75\% дійсної } \\
\text { вартості }\end{array}$ & $\begin{array}{c}\text { Більше 75\% дійсної } \\
\text { вартості }\end{array}$ & $\begin{array}{c}\text { Більше 75\% дійсної } \\
\text { вартості }\end{array}$ \\
\hline $\begin{array}{c}\text { Наявність знижок та } \\
\text { надбавок («бонус- } \\
\text { малус») }\end{array}$ & немає & немає & $€$ \\
\hline $\begin{array}{c}\text { Норматив витрат на } \\
\text { ведення справи в } \\
\text { страховому тарифі }\end{array}$ & $\begin{array}{c}\text { До 40\% } \\
\text { брутто - ставки }\end{array}$ & $45 \%$ & $45 \%$ \\
\hline $\begin{array}{c}\text { Наявність розстрочки } \\
\text { у сплаті страхової } \\
\text { премії }\end{array}$ & $€$ & $€$ & $€$ \\
\hline
\end{tabular}

До інших умов страхування було включено також розмір нормативних витрат на ведення справи, що встановлені в страховому тарифі та складають 40\% в АХА Страхування та $45 \%$ у інших компаніях. Чому саме треба звертати увагу на цей показник? За законом України «Про страхування» передбачено можливість дострокового розірвання договору страхування 3 ініціативи будь якої сторони страхувальника або страховика. Якщо ініціатива виходить від клієнта та вона не пов'язана із порушенням умов договору з боку страховика, то розрахунок страхової премії, що повертається клієнтові враховує норматив витрат і на цю суму зменшує розмір суми до повернення. Це означає, що чим вищим є цей показник, тим менш привабливим є компанія для клієнта.

Нарешті важливими є також умови визнання збитків тотальними, тобто такими, коли немає сенсу детально розраховувати розмір збитків через різні причини, наприклад, коли візуально ясно, що має місце конструктивне руйнування ТЗ та втрати наближаються до дійсної вартості ТЗ. Як видно з табл. 2 умовою визнання тотального збитку у наведений компаніях є розмір втрат вищий за 75\% дійсної вартості T3, хоча такий відсоток може бути іншим.

Розглянуті параметри страхового продукту є лише базовими для визначення привабливості КАСКО для клієнта.

Цікавим також $є$ такий момент - в Україні на сайті страховика повинні розміщуватися правила страхування по всіх видах заліцензованих страхових послуг та будь хто може ознайомитися 3 ними. В європейських компаніях немає такої інформації у відкритому доступі, а конкретні умови страхування прописуються лише в договорі 3 клієнтом.

Проте, враховуючи особливості страхових послуг, що є невід'ємними від їх постачальника, принциповим $€$ оцінка надійності компанії, іiї тарифної політики, розвитку сервісу.

Надійність страховика визначається його фінансовими можливостями виконання зобов'язань перед клієнтами. Найбільш показовим є популярність певної страхової компанії в суспільстві, iï позитивна оцінка 3 боку клієнтів та їх знайомих щодо обслуговування при укладанні договорів та при врегулюванні страхових випадків. Кількісним показником такої оцінки є страхові платежі за КАСКО, інформація про які є загальнодоступною, наприклад, на сайті Форіншурер. Там же представлений рейтинг компаній по різних параметрах (виплатах, перестрахуванні, активах компанії та інш.), крім того є калькулятор КАСКО, за допомогою якого розраховується вартість у провідних компаніях. Всі розрахунки безкоштовні, інформація об'єктивна, тому що 
отримана від менеджерів компаній. Щодо тарифної політики в КАСКО та цьому ж ресурсі є розділ тарифи та статті за найбільш важливими питаннями, наприклад, від чого залежить тариф, як зменшити вартість страхування та т.П. На страховому ринку України сьогодні вже навіть можна скористатися такою програмою як «Признач свою ціну КАСКО» - клієнт пропонує певну суму за договір страхування, а страхова компанія підбирає для нього умови страхового захисту.

Для осіб з певним рівнем економічних знань оцінка фінансової надійності страховика здійснюється за даними фінансової звітності компаній.

До основних показників оцінки надійності страхової компанії відносяться:

1. Розмір власного та залученого капіталу як в абсолютній сумі, так і в коефіцієнтах по відношенню до суми страхових резервів, до валюти балансу, до обсягу страхової відповідальності.

2. Участь перестраховиків в забезпеченні ризиків компанії та склад таких компаній.

3. Темпи зростання активів страхових компаній та оцінка їх якості. За новими вимогами до якості активів страховиків оцінюється достатність активів та їх диверсифікація [12].

4. Розглядаються також терміни здійснення страхових виплат за договорами страхування та кількість скарг на страховиків.

Це лише невелика кількість показників оцінки надійності страхових компаній щодо виконання зобов'язань по договорах страхування, але у статті ставилась мета розглянути оцінку привабливості КАСКО з боку страхувальника.

Висновки. Страхування ризиків автотранспорту є основою договорів КАСКО, які мають високу популярність серед всіх видів страхових послуг в країні, насамперед 3 того, що достатньо чітко відстежується страховий інтерес споживача такої послуги. Значна кількість страхових компаній i, в першу чергу, провідних та достатньо великих за обсягами операцій, а також компаній 3 іноземним капіталом, мають в портфелі значну частку договорів КАСКО. Для оцінки привабливості було розглянуто практику та умови страхування в ТОР 3 страховиків України за преміями по КАСКО та зроблено порівняння, що дозволило визначити основні параметри продукту та підходи до вибору компанії.

Перспективним напрямом подальших досліджень вважається визначення андерайтингової політики страхової компанії в умовах розвитку технічної бази Т3 та переходу на авто пілотування. Компаніям треба готуватися до нових ризиків та чинників збитковості в договорах КАСКО.

\section{Література:}

1. Свешников С.В., Бочарников В.П. Основы нечеткой технологии и примеры решения аналитических задач в государстве и бизнесе. М. ДМК Пресс. 2014. - 408 с.

2. Сокіл Л. Вплив фінансової грамотності населення на формування раціональної споживчої поведінки на ринку страхових послуг. Світ фінансів. 2012. №1. C. $155-162$

3. Статистика страхового ринку України. URL. : https://forinsurer.com/stat (дата звернення: 27.11.2018)

4. Как оценить качество страховой услуги? В. Г. Гречанюк. URL: http://www.ins-consul.ru (дата звернення: 28.11.2018).

5. Приказюк Н.В., Моташко Т. П. Нові вектори розвитку автотранспортного страхування в Україні. URL: http://papers.univ.kiev.ua/1/ekonomika/articles/prikazyuk- 
nmotashko-t-new-vectors-of-the-motor-insurance-development-in-ukrai_24576.pdf (дата звернення 2.10.2018)

6. Автомобільне страхування в системі безпеки дорожнього руху: [Кол. моногр.] / [О.М. Залєтов, О.В. Кнейслер, В.М. Стецюк, О.Ю. Толстенко та ін. ]; Наук. ред. та кер. кол. авт. О.М. Залєтов. - К.: Міжнародна агенція "BeeZone", 2012.- 509 с.

7. Digital distribution in insurance: a quiet revolution. Swiss Re sigma. № 2. 2014. URL:http://www.the-digital-insurer.com/wp-content/uploads/2014/06/295-sigma2 2014en.pdf (дата звернення: 20.11.2018 p.)

8. Ткаченко Н. В., Криниця С. О. Аналіз сучасного ринку добровільного страхування автотранспортн их засобів в Україні URL: https://fp.cibs.ubs.edu.ua/files/1304/13tnvasr.pdf (дата звернення: 1.12.2018 p.)

9. Салайчук О.М. Генезис автотранспортного страхування. Економічні науки. Вісник Хмельницького національного університету. 2016. №2. T. 1. С. 129-134. URL: http://journals.khnu.km.ua/vestnik (дата звернення 12.11.2018 p.)

10. Носенко М.С., Мочона Л.Г. Шахрайство в сфері страхування та методи боротьби 3 ним. Економіка та держава. 2012. № 5. C. 113-115 URL: http://www.economy.in.ua/pdf/5_2012/31.pdf (дата звернення: 8.12.2018)
11. Что ждёт
страховщиков
Европы
URL: https://forinsurer.com/public/18/09/04/4825 (дата звернення: 23.12.2018)

12. Положення про обов'язкові критерії і нормативи достатності капіталу та платоспроможності, ліквідності, прибутковості, якості активів та ризиковості операцій страховика. URL: http://www.nfp.gov.ua (дата звернення: 28.12.2018)

13. Офіційний сайт CK «AXA Страхування». URL: https://axa-ukraine.com/ (дата звернення: 23.12.2018)

14. Офіційний сайт СК УНIКА. URL http://uniqa.ua/ (дата звернення: 4.12.2018)

15. Офіційний сайт СК «Арсенал Страхування». URL. https://arsenal-ic.ua/ (дата звернення: 5.12.2018)

16. Міністерство інфраструктури України. https://mtu.gov.ua/content/statistichni-dani-po-galuzi-avtomobilnogo-transportu.html (дата звернення: 2.12.2018) 